\title{
Yield response of spring wheat to increasing densities of spring oats and various forms of post-emergence weed control
}

\author{
JP Caussanel 1, B Kafiz 1, A Carteron 2 \\ 1 INRA, Laboratoire de Malherbologie; \\ 2 INRA, Station d'Amélioration des Plantes, BV 1540, F-21034 Dijon Cedex, France
}

(Received 9 September 1992; accepted 11 August 1993)

\begin{abstract}
Summary - Reductions in the yields of spring wheat (cv Bastion) caused by interference from spring oat (cv Selma), considered as a weed, were estimated in field studies on post-emergence weed control in Dijon (France). The growth and development of both plants in competition was different for each of the 3 experimental years. Wheat yield losses were significantly greater on oat-infested plots than on plots treated with diclofop-methyl. A hyperbolic model provided an excellent fit to data for both wheat-grain yield and ear density as a function of oat density, measured at the beginning of tillering. On infested plots where the oats was left to grow until harvest, the number of grains per wheat ear decreased with increasing oat density, and weight-per-grain was not affected. On plots where diclofop-methyl was not applied, chemical control of broad-leaf weeds did not increase wheat yield. On plots controlled with diclofop-methyl, the per cent wheat yield losses differed with the chemical weed control of broad leaf weeds used. When diclofopmethyl and 2,4-D were applied on the same day, the number of wheat ears $\mathrm{m}^{-2}$ was lower than for other diclofopmethyl + antidicotyledoneous herbicide applications. These results show that competitive interference between weeds and crop plants can be modified by the sequence of herbicides applied, so altering the measured crop yield components.
\end{abstract}

yield loss / weed interference / spring wheat / spring oat / broad-leaf weed control / diclofop-methyl / 2,4-D

Résumé - Réponses du rendement du blé tendre de printemps à des densités croissantes d'avoine de printemps en combinaison avec diverses formes de lutte chimique herbicide de post-levée. Des expériences de plein champ ont été conduites en 1984, 1985 et 1986, afin de déterminer les effets de densités croissantes d'avoine de printemps (Avena sativa $L \mathrm{cv}$ Selma), considérée comme une mauvaise herbe, sur la croissance et le rendement du blé de printemps (Triticum aestivum $L$ cv Bastion) en relation avec le désherbage. Les 2 espèces ont été semées le même j. Dans la moitié des parcelles, l'avoine a été éliminée en appliquant du diclofop-méthyl au stade 2 à 3 talles du blé. Des infestations naturelles de dicotylédones adventices ont été soit: 1) laissées sur les parcelles; 2) maitrisées avec l'association herbicide «ioxynil + mécoprop"; 3) maitrisées avec une application précoce de 2,4-D;4) maitrisées avec une application tardive de 2,4-D. Le diclofop-méthyl s'est montré hautement efficace chaque année et aucune plante d'avoine n'était présente sur les parcelles traitées, une sem après le désherbage au diclofop-méthyl. Lorsque la densité d'avoine s'élève, la production en grain du blé, comme le nombre d'épis par $m^{2}$ diminue fortement sur les parcelles infestées en avoine et faiblement sur les parcelles traitées au diclofop-méthyl. Sur les parcelles infestées en avoine jusqu'à la récolte, le nombre de grains par épi décroit quand la densité d'avoine augmente alors que le poids de 1000 grains n'est pas réduit. Les effets du désherbage chimique des mauvaises herbes dicotylédones sur le rendement du blé sont à examiner en fonction du traitement au diclofop-méthyl. Sur les parcelles non traitées au diclofop-méthyl, sa réalisation ne se traduit jamais par une augmentation du rendement du blé, ce qui peut s'expliquer par le faible pourcentage de biomasse des mauvaises herbes dicotylédones par rapport à la biomasse végétale totale (moins de 5\%). En revanche, sur les parcelles traitées au diclofop-méthyl, lorsque le diclofop-méthyl et le 2,4-D sont appliqués le même $j$ (application précoce de 2,4-D), le nombre d'épis par $\mathrm{m}^{2}$ de blé à la récolte est diminué comparativement à d'autres traitements diclofop-méthyl + herbicides antidicotylédones. Sur les parcelles traitées au diclofopméthyl, des augmentations du nombre de grains par épi en 1985 et du poids de 1000 grains en 1984 et en 1985 ont été constatées sur les parcelles traitées précocement par des herbicides antidicotylédones. Ces résultats montrent que les interactions de compétition entre mauvaises herbes et plantes cultivées peuvent changer au cours de l'application d'une séquence d'herbicides à cause des effets sur les composantes du rendement. 


\section{INTRODUCTION}

Wild oat species are some of the most difficult annual grass weeds to eradicate from cereal crops (Holm et al, 1977). Four oat species are serious weeds in European cereals and all are widely distributed in France (Barralis, 1961; Jauzein and Montegut, 1983): Avena fatua L; $A$ sterilis L ssp ludoviciana (Durieu) Nyman; $A$ sterilis L ssp sterilis; and A barbata Pott ex Link/Brot.

Wild oats have been reported to reduce wheat yields in many countries (Friesen and Shebeski, 1960; de Gournay, 1964; Bell and Nalewaja, 1968; Chancellor and Peters, 1974; Paterson, 1976; Rolston, 1981; Madeira et al, 1984; Fernandez-Quintanilla et al, 1987). Cultivated oats were used rather than wild oats in some experiments on competition in mixtures with other crops (Trenbath and Harper, 1973) and to avoid difficulties of germination and contamination (Pfeiffer and Holmes, 1961).

These studies have shown that wheat yield losses increase with wild oat density. Several regression models have been fitted to data describing wheat yield as a function of wild oat density (Dew, 1972) or of the relative density of wild oats in the total plant stand (Carlson and Hill, 1985). Our preliminary study (Caussanel et al, 1988) showed a linear relationship between the decrease in spring wheat yield (Triticum aestivum $\mathrm{L} c \mathrm{v}$ Bastion) and increasing spring oat density (Avena sativa L cv Selma) with oat densities from 0 to 160 plants $/ \mathrm{m}^{2}$. Two further field experiments were carried out in 1985 and 1986.

The objectives of the whole study were, first, to establish a relationship between wheat yield and oat density using a regression model suitable for an agronomic situation of weed competition. Both linear and non-linear models have been used to describe the relationship between crop yield and weed density in order to define weed thresholds for spraying (Cousens et al, 1984). A non-linear "rectangular hyperbola" model (Cousens, 1985) proved to be highly effective over a wide range of weed densities, in such crops as wheat (Wilson and Wright, 1990) and tomato (Weaver et al, 1987; Caussanel et al, 1990).

The second objective was to determine how the response of wheat yield to oats density is affected by eliminating the oats at an early wheat growth stage. When wheat and oats are allowed to grow together until harvest, the oats are often very strong competitors of spring cereals. Any attempt at controlling a grass weed in the field must be based on knowing how long the grass weed can be allowed to grow without any further effect on wheat yield. For spring cereals in England, Chancellor and Peters (1974) established that the best time to remove wild oats (Avena fatua $L$ ) by hand picking was about $4-5$ weeks after emergence, when the crop was at the 4-leaf stage. For spring wheat in Canada, wheat yield losses were reported when wild oats were removed as early as the 2-3 leaf stage of the crop, with high densities of wild oats up to 240 plants/ $\mathrm{m}^{2}$ (Bowden and Friesen, 1967). In wheat crops, the scheme of yield elaboration (Meynard, 1985) highlights the relationships between yield components. Weed competition damage (Saut, 1981), drought, or lack of nitrogen dressing (Sebillotte et al, 1978) all can alter some of the yield components, depending on when they occur during the wheat growing cycle. We measured wheat yield components in our experiments to determine the effects of oat competition and herbicide damage.

Our third objective was to determine whether improvement in yield expected after controlling oats in a wheat crop with diclofop-methyl depended on broad-leaf weed control. From a practical point of view, the use of different kinds of weed control in wheat crops can cause changes in the weed competition profile. The timing and technique of weed elimination are important factors (Caussanel, 1973). The use of different herbicides to suppress the competition from increasing densities of a weed in cereals can sometimes lead to phytotoxic effects of herbicide interactions. These effects are more complex in experiments where multi-specific interactions occur, because yield responses following weed removal may be less evident due to damage to the crop by herbicides (Wilson and Cussans, 1978). These authors found that winter wheat yield was more influenced by the time of weed removal than by the degree of control achieved. Field and laboratory applications of a mixture of diclofopmethyl and auxin-type herbicides such as 2,4-D or MCPA showed a significant loss of diclofopmethyl activity on Avena species, without any decrease in 2,4-D toxicity for dicotyledons (Todd and Stobbe, 1980; Taylor et al, 1983). Under controlled conditions, a mixture of diclofopmethyl and 2,4-D reduced the toxicity of the diclofop-methyl to Avena fatua and Avena sativa (cv Selma) at the 2.5-leaf stage (Kafiz et al, 1989). 


\section{MATERIALS AND METHODS}

Field experiments were conducted during 1984, 1985 and 1986 at the INRA experimental farm (Domaine expérimental d'Epoisses, Dijon $\left(47^{\circ} 18 \mathrm{~N}-5^{\circ} 03^{\prime} \mathrm{E}\right)$. The soil is a clay loam ( $7 \%$ sand, $60 \%$ silt, $33 \%$ clay) with an organic matter content of $3.0 \%$ and a pH of 7.2 (Eutric Cambisol in the FAO soil classification). Phosphate as triphosphate $\left(\mathrm{P}_{2} \mathrm{O}_{5}, 115 \mathrm{~kg} / \mathrm{ha}\right)$, and potash as potassium sulphate $\left(\mathrm{K}_{2} \mathrm{O}, 115 \mathrm{~kg} / \mathrm{ha}\right)$, were applied in the autumn and 2 applications of ammonium nitrate (nitrogen, $55 \mathrm{~kg} / \mathrm{ha}$ ) at tillering, and again at stem elongation in the spring.

Wheat seeds (cv Bastion) were drilled to obtain an expected density of 350 plants $/ \mathrm{m}^{2}$, and oats seeds (cv Selma) were drilled in the wheat interrow at a range of experimental densities. The average percentage of germinated seeds was determined after 3 days in a growth chamber at $10^{\circ} \mathrm{C}$ during the dark period and $15^{\circ} \mathrm{C}$ during the $12-\mathrm{h}$ light period. This was used to calculate the weight of wheat or oats seeds to drill for each plot. Both cereals were sown on the same day, in rows $15 \mathrm{~cm}$ apart.

The experimental design was a randomized complete block with 5 replicates. Three factors were studied in a split-split-plot design: i) diclofop-methyl treatment as the main plot; ii) the seeding rate of oats as sub-plot; and iii) herbicide for broad-leaf weed control as sub-sub-plot. Main plots (presence or absence of diclofop-methyl treatment, as an "oat herbicide") were composed of 6 sub-plots where the expected spring oats densities were $A=0, B=10, C=20, D=40, E=$ 80 and $F=160$ plants $/ \mathrm{m}^{2}$. Each sub-sub-plot was sprayed at a different date with a broad-leaf herbicide to control natural infestations of broad-leaf weeds. In the design, each combination of levels of factors was repeated twice on 2 adjacent sub-sub-plots.

Diclofop-methyl was applied at $1080 \mathrm{~g} / \mathrm{ha}$ at the 23-tiller stage of wheat, stage 22 on the Zadoks scale (Zadoks et al, 1974). The broad-leaf herbicide treatments in 1984 were: control; 2,4-D early application; and 2,4-D late application. In 1985 and 1986, treatments were: control; ioxynil + mecoprop; $2,4-D$ early application; and 2,4-D late application. The ioxynil + mecoprop mixture was applied at $375 \mathrm{~g} /$ ha plus 937.5 $\mathrm{g} / \mathrm{ha}$, when both wheat and oats reached the Zadoks leaf stage 12. 2,4-D was used as a formulated dimethylamine salt and applied at $480 \mathrm{~g} / \mathrm{ha}$. Early weed control was carried out at wheat leaf stage 22 on the same dates as for diclofop-methyl application. A late control treatment was applied at the wheat leaf stage 33. The temperature and rainfall conditions were measured throughout the growth cycle of wheat each year (Kafiz, 1989).

Six rows of wheat and 7 of oats were sown per subsub-plot $(1.25 \times 7 \mathrm{~m})$. One sub-sub-plot, designated the "harvest plot", was harvested to measure wheat yield and yield components. After harvesting borders and a total area of $0.90 \mathrm{~m}^{2}$ as sample in each sub-subplot, the area remaining was $4.5 \mathrm{~m}^{2}$. On the other adjacent sub-sub-plot, designated the "biomass plot", veg- etative growth was assessed by destructive sampling on 3 or 4 occasions during the growing season. Measurements of plant and tiller densities and shoot biomass were made in 2 quadrats per sub-sub-plot.

Wheat and oats densities were determined in 2 $0.45 \times 1.0 \mathrm{~m}$ quadrats per harvest plot after the crop was established. Wheat yield components (number of ears $/ \mathrm{m}^{2}$, number of grains/ear and weight/grain) were determined before the plots were harvested.

Plant and tiller densities and shoot biomass were determined every $2 \mathrm{wk}$ in biomass plots during the period between the graminicide treatment and the flowering stage of the wheat. Shoot biomass was determined on the control plots, ie those without herbicide treatment; samples were oven-dried at $95^{\circ} \mathrm{C}$ for $48 \mathrm{~h}$. This destructive sampling was done in $20.45 \mathrm{x}$ 1.0 quadrats separated by $0.25 \mathrm{~m}$ buffers. In the other 2 quadrats, ear and panicle densities were measured at the milky grain stage.

The wheat and oat from a surface area of $4.5 \mathrm{~m}^{2}$ in harvest plots were threshed and cleaned after grain maturity was reached. Grains were separated with a grain sorter/grader and wheat and oats yields were determined from a sample tested for grain moisture, assuming a $15 \%$ moisture content.

\section{Statistical analyses}

Data were analysed by analysis of variance and the significance ( $F$-value) of each factor and interaction between the 3 factors ("oat density", "oat herbicides" and "broad-leaf herbicide") were determined (SAS, 1988). The treatment sum of squares was partitioned into main effects and interactions (Little, 1981) and regression procedures involving the density effect were used (Caussanel et al, 1990). Two models were used to describe the relationship between oat density and wheat yield over a given range of densities:

linear or quadratic:

$$
y=y_{0}-a x ; y=y_{0}-a x+b x^{2}
$$

non-linear (Cousens, 1985):

$$
y=y_{0}[1-(i x /(1+k x))]
$$

where $y_{0}$ is the wheat yield without oat competition; $x$ is the oat density assessed at early tillering (time of graminicide treatment); and $a, b, i, k$ are empirical parameters describing the intensity of oat competition effects in the regression model used. Data were fitted to a linear or a non-linear equation using the leastsquares iterative procedure in the SAS statistical package (SAS, 1988).

When the interaction "oat-herbicide $\mathrm{x}$ broad-leaf herbicide" was significant, mean data for the factor broad-leaf-herbicide were compared for each level of oat herbicide treatment (Duncan, 1955). Critical ranges were calculated for the number of means com- 
pared (SAS, 1988) and significant differences are included in the tables.

\section{RESULTS}

\section{Growth and development of wheat and oats in competition}

The wheat sowing date was delayed in 1986 because of high rainfall; cold weather and soil dryness were more pronounced after the sowing dates in 1984 and 1985. Field data are shown in table 1.

All changes in wheat and oat density were determined between the wheat stages 12 and 22 . In 1984 and 1986, the mean density of wheat at stage 22 was over $95 \%$ of the expected stand density of 350 plants $/ \mathrm{m}^{2}$, and it was the same for oats in 1986 (table II). Oat density at stage 22 was consistently lower $(75 \%)$ than at stage 12 in 1984. There was no significant correlation between oat density at emergence and subsequent mortality of this plant (Kafiz, 1989), hence there was no intraspecific oats competition. In 1985, because of cold spring weather and delayed emergence of both cereals, the density at stage 12 was $75 \%$ for wheat and $85 \%$ for oats, compared to the sowing density. The germination rates were $97.8,89.3$ and 95.2 for wheat and 85.0, 83.3 and 79.1 for oats, in 1984, 1985 and 1986 , respectively. However, the oats stand den- sity was higher than expected in 1986, probably because of delayed germination of the seed lot.

The oats dry weight per unit area on plots without weed control increased with increasing oat density, and wheat dry weight decreased (fig 1). Total dry weight per unit area was higher in 1984 and 1985 than in 1986. In 1985, the percentage of oats increased markedly from $22 \%$ at stage 22 to $43 \%$ at stage 59 at all sowing densities. But in 1984 and 1986, the mean oat percentage increased slowly from $15 \%$ to $21 \%$. The dry weight of broad-leaf weeds contributed to less than $5 \%$ of the total dry weight of the control plots without oat infestation in all the years tested. It declined as oats density increased. The broad-leaf species were: Aethusa cynapium L, Amaranthus retroflexus L, Capsella bursa pastoris $(\mathrm{L})$ Medik, Chenopodium album L, Euphorbia exigua L, Fallopia convolvulus (L) Löve, Kickxia spuria L, Polygonum aviculare L, Polygonum persicaria $\mathrm{L}$, Thlapsi arvense $\mathrm{L}$ and Sinapis arvensis L.

On plots without weed control, the wheat grain yield was higher in 1984 and 1986 than in 1985 (fig 2a), and the number of oat panicles $/ \mathrm{m}^{2}$ at harvest increased with oat density (fig $2 b$ ). The contribution of oats to the total stand (wheat ears and oat panicles $\left./ \mathrm{m}^{2}\right)$ was greater in 1985 (23\% as an average of all densities) than in 1986 (15\%) and 1984 (12\%). The average percentages of oats in the total grain yield were similar in $1984(22 \%)$ and $1986(20 \%)$ but higher in 1985 (50\%).

Table I. Field experimental data.

\begin{tabular}{|c|c|c|c|}
\hline & 1984 & 1985 & 1986 \\
\hline Previous crop (year before) & Spring barley & Winter wheat & Spring peas \\
\hline Sowing date & 8 March & 8 March & 14 April \\
\hline Wheat 2-leaf stage & 10 April & 22 April & 7 May \\
\hline $\begin{array}{l}\text { Herbicide application: } \\
\text { loxynil + mecoprop } \\
\text { Diclofop-methyl } \\
\text { 2,4-D (1st date) } \\
\text { 2,4-D (2nd date) }\end{array}$ & $\begin{array}{l}15 \text { May } \\
15 \text { May } \\
28 \text { May }\end{array}$ & $\begin{array}{r}23 \text { April } \\
7 \text { May } \\
7 \text { May } \\
20 \text { May }\end{array}$ & $\begin{array}{c}12 \text { May } \\
22 \text { May } \\
22 \text { May } \\
2 \text { June }\end{array}$ \\
\hline Milky grain stage & 10 July & 1 July & 1 July \\
\hline Maturity & 9 August & 10 August & 12 August \\
\hline Harvest & 16 August & 14 August & 17 August \\
\hline
\end{tabular}


Table II. Oats densities at various stages of wheat development (data from control biomass plots).

\begin{tabular}{|c|c|c|c|c|}
\hline \multirow[t]{2}{*}{ Year } & \multirow{2}{*}{$\begin{array}{l}\text { Expected densities } \\
\left.\text { (plants } / m^{2}\right)\end{array}$} & \multicolumn{3}{|c|}{ Number of oats plants $/ \mathrm{m}^{2}$} \\
\hline & & Stage 12 & Stage 22 & Stage 59 \\
\hline \multirow[t]{6}{*}{1984} & 0 & 0 & 0 & 0 \\
\hline & 10 & 12 (4) & 9 (3) & $12(4)$ \\
\hline & 20 & 19 (4) & $16 \quad(3)$ & $18 \quad(4)$ \\
\hline & 40 & $41 \quad(7)$ & $30(10)$ & $23 \quad(6)$ \\
\hline & 80 & $78 \quad(8)$ & $64 \quad(9)$ & 59 (8) \\
\hline & 160 & $167(24)$ & $115(10)$ & $87(8)$ \\
\hline \multirow[t]{6}{*}{1985} & 0 & 0 & 0 & 0 \\
\hline & 10 & $10 \quad(2)$ & $12(4)$ & $12(4)$ \\
\hline & 20 & $19(6)$ & $20 \quad(5)$ & $22(6)$ \\
\hline & 40 & $36 \quad(6)$ & $41 \quad(7)$ & 39 (7) \\
\hline & 80 & $71(19)$ & $80(11)$ & 71 (2) \\
\hline & 160 & $139(6)$ & $156(19)$ & $126(17)$ \\
\hline \multirow[t]{6}{*}{1986} & 0 & 0 & 0 & 0 \\
\hline & 10 & $14 \quad(3)$ & $11 \quad(3)$ & $15 \quad(5)$ \\
\hline & 20 & $24 \quad(5)$ & $18 \quad(3)$ & 24 (5) \\
\hline & 40 & 49 (7) & $43 \quad(8)$ & $46 \quad(5)$ \\
\hline & 80 & 101 & $98(11)$ & $93(12)$ \\
\hline & 160 & 195 (4) & $169(8)$ & $172(12)$ \\
\hline
\end{tabular}

Numbers in parentheses: standard errors.
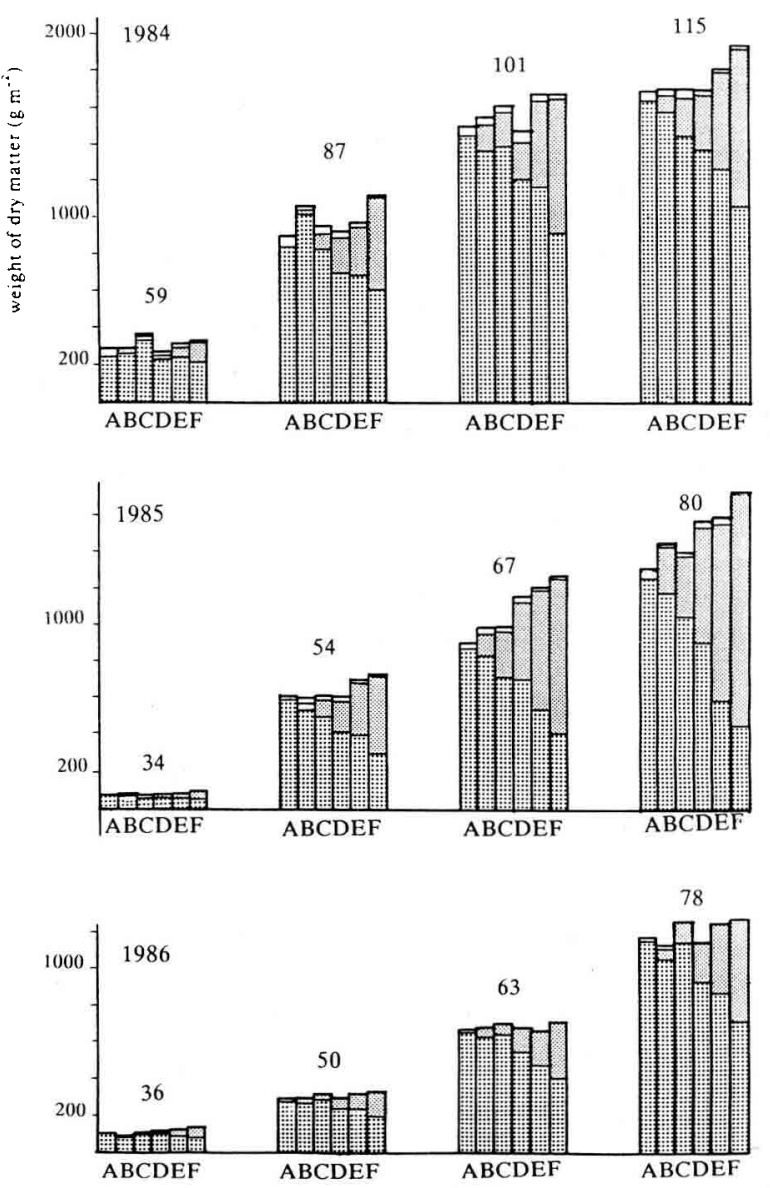

\section{Effects on wheat yield loss in relation to herbicide application}

Diclofop-methyl was highly effective and provided excellent control of the target species in all years. No oat plants were found alive $1 \mathrm{wk}$ after its application. As the diclofop-methyl $x$ oat density interaction was significant for wheat yield every year (table III), the relationship between wheat yield and oat density was calculated for each level of diclofop-methyl. The regression equations indicate that the wheat yield loss dropped as the density of oats increased (fig 3). The losses were greater when oats was allowed to grow until harvest than when it was controlled at early tillering. Thus the percentage wheat yield losses were calculated to be $10.6 \%$ in $1984,21.8 \%$ in 1985 and $8.7 \%$ in 1986 when 20 oat plants $/ \mathrm{m}^{2}$ were present up to harvest. When these oat plants $/ \mathrm{m}^{2}$ were controlled at early til-

Fig 1. Influence of oat density on weight of dry matter of wheat, oats and broad-leaf weeds at different wheat growth stages (data from control biomass plots). A, B, C, D, E, F: increasing oat densities; numbers above histograms: days from sowing: wheat dry matter; oats dry matter; $\square$ broad-leaf weeds dry matter. 

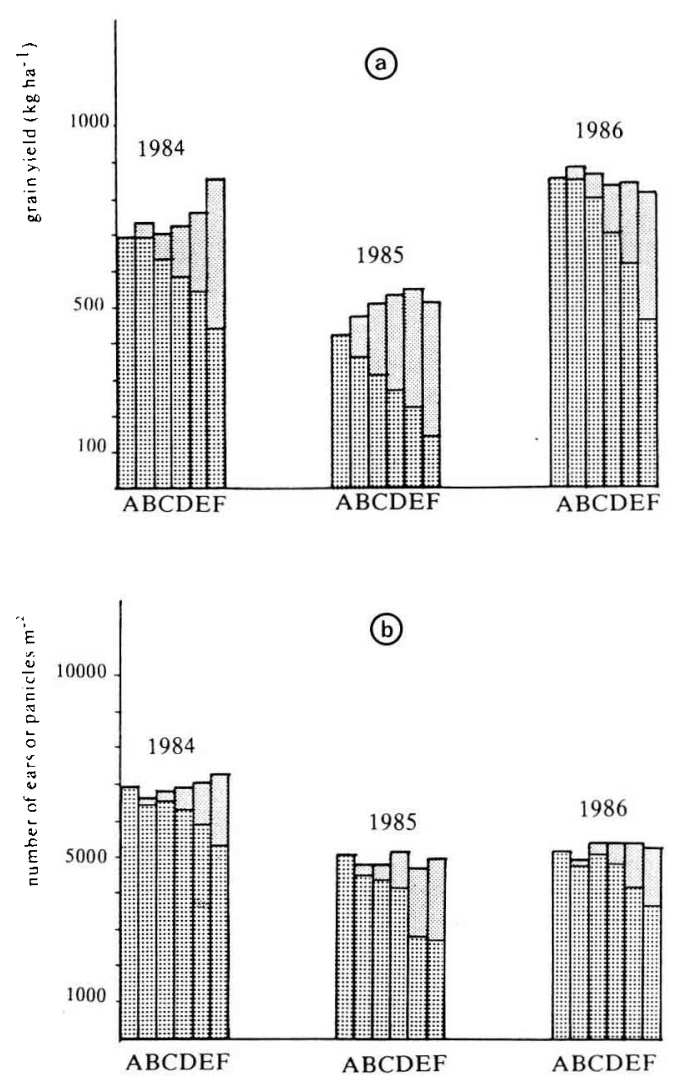

Fig 2. Influence of oat density on yield of wheat and oats in 1984, 1985 and 1986 (data from control biomass plots): a) number of ears or panicles $\mathrm{m}^{-2}$; b) grain yield $\left(\mathrm{kg} / \mathrm{ha} \mathrm{a}^{1}\right) ; \mathrm{A}, \mathrm{B}$, $C, D, E, F$ : increasing oat densities; numbers above histograms: years; 1 wheat yield;

lering of wheat, the losses were only $6.5 \%, 3.1 \%$ and $2.2 \%$.

Oat density also reduced the number of ears of wheat per unit area. As the diclofop-methyl $x$ oat density interaction was not significant in 1984 (table IV), although the effect of each factor was significant $(P<0.05)$, the influence of density on number of ears $\mathrm{m}^{-2}$ was described by 2 parallel regression lines (fig 4). As the diclofopmethyl $x$ oat density interaction was significant in 1985 and 1986 (table IV), a regression equation was calculated for each level of diclofop-methyl (fig 4).

Broad-leaf herbicide treatment significantly affected grain yield and number of ears per unit area. The diclofop-methyl $x$ broad-leaf herbicide interaction was also significant for both variables every year (tables III-IV). When oats were not controlled with diclofop-methyl, there was no significant change in wheat yield after the broadleaf herbicide application in 1984 (table Va). Wheat grain yield was higher on plots controlled with early application of ioxynil + mecoprop in

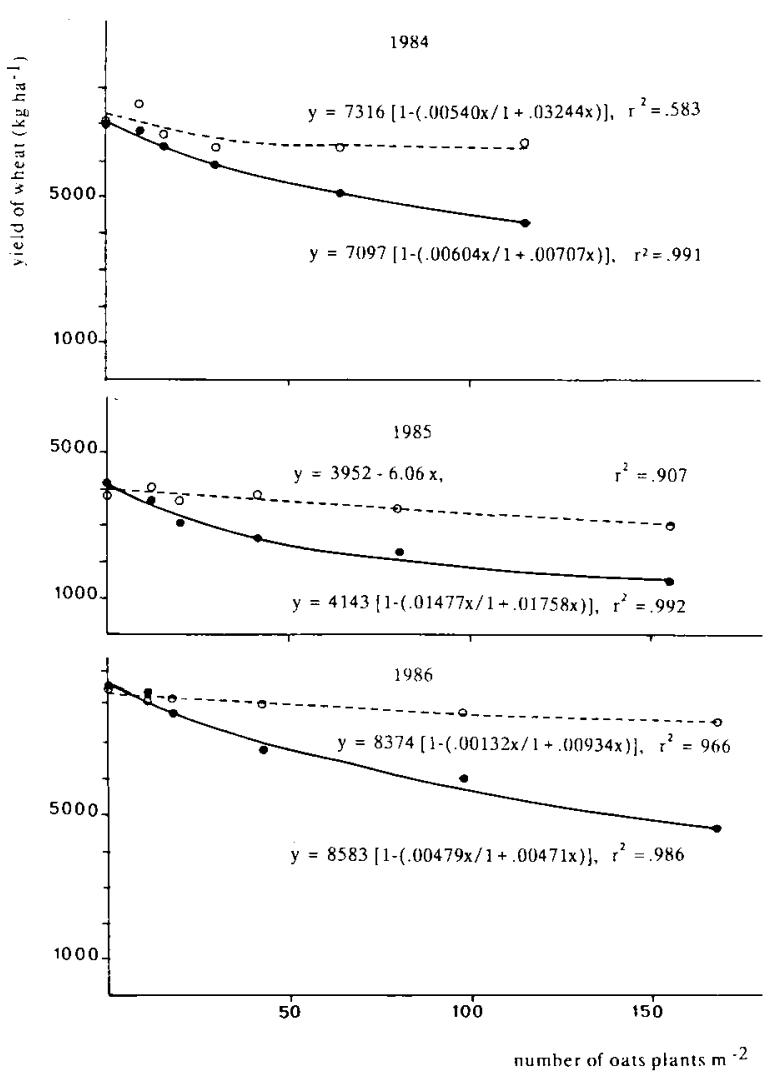

Fig 3. Relationship between oat density at wheat stage 22 and yield of wheat with and without diclofop-methyl treatment: 00 no diclofop-methyl; OOO diclofop-methy!.

1985 than on plots not treated with broad-leaf herbicide. When the competition from oats was suppressed by applying diclofop-methyl at early tillering, early application of 2,4-D influenced the wheat yield, increasing it in 1984 and 1985 and decreasing it in 1986 (table $\mathrm{Va}$ ). The ear density of wheat was reduced when 2,4-D was applied early, ie on the same day as the diclofop-methyl treatment, in all years (table $\mathrm{Vb}$ ). The oat density $x$ broad-leaf herbicide interaction was not significant $(P>0.05)$ for any of the variables measured in the experiments (tables III, IV and VI).

\section{Effects on wheat yield components}

The samples from the quadrats indicated significant effects for wheat yield and for the number of wheat ears per unit area in 1984 and 1985 (table $\mathrm{VI})$. The main effects and interactions were similar to those for whole harvest plots, except for the broad-leaf herbicide effect on wheat yield (table III). The number of grains per ear was re- 
Table III. Analysis of variance of spring wheat yields as influenced by cultivated oats density and broad-leaf herbicide in 1984, 1985 and 1986 (data from harvest plots).

\begin{tabular}{|c|c|c|c|c|c|}
\hline Year & Factor & $\begin{array}{l}\text { Degrees of } \\
\text { freedom }\end{array}$ & Sum of squares & F-value & Probability level \\
\hline 1984 & $\begin{array}{l}A=\text { diclofop-methyl } \\
\text { Error } 1 \\
B=\text { oats density } \\
A \times B \\
\text { Error } 2 \\
C=\text { broad-leaf herbicide } \\
A \times C \\
B \times C \\
\text { Error } 3\end{array}$ & $\begin{array}{r}1 \\
4 \\
5 \\
5 \\
40 \\
2 \\
2 \\
10 \\
106\end{array}$ & $\begin{array}{r}2977 \\
2955 \\
7443 \\
2040 \\
4306 \\
165 \\
378 \\
122 \\
2749\end{array}$ & $\begin{array}{r}4.03 \\
13.83 \\
3.79 \\
\\
3.18 \\
7.30 \\
0.47\end{array}$ & $\begin{array}{l}\text { NS } \\
0.001 \\
0.01 \\
0.05 \\
0.01 \\
\text { NS }\end{array}$ \\
\hline 1985 & $\begin{array}{l}A=\text { diclofop-methyl } \\
\text { Error } 1 \\
B=\text { oats density } \\
A \times B \\
\text { Error } 2 \\
C=\text { broad-leaf herbicide } \\
A \times C \\
B \times C \\
\text { Error } 3\end{array}$ & $\begin{array}{r}1 \\
4 \\
5 \\
5 \\
40 \\
3 \\
3 \\
15 \\
159\end{array}$ & $\begin{array}{r}3431 \\
443 \\
8176 \\
2180 \\
784 \\
547 \\
259 \\
110 \\
700\end{array}$ & $\begin{array}{r}30.96 \\
\\
83.41 \\
22.24 \\
4.45 \\
41.41 \\
19.58 \\
1.66\end{array}$ & $\begin{array}{l}0.01 \\
0.001 \\
0.001 \\
0.001 \\
0.001 \\
\text { NS }\end{array}$ \\
\hline 1986 & $\begin{array}{l}A=\text { diclofop-methyl } \\
\text { Error } 1 \\
B=\text { oats density } \\
A \times B \\
\text { Error } 2 \\
C=\text { broad-leaf herbicide } \\
A \times C \\
B \times C \\
\text { Error } 3\end{array}$ & $\begin{array}{r}1 \\
4 \\
5 \\
5 \\
40 \\
3 \\
3 \\
15 \\
159\end{array}$ & $\begin{array}{r}5867 \\
91 \\
15682 \\
7501 \\
1267 \\
1036 \\
255 \\
105 \\
1840\end{array}$ & $\begin{array}{r}257.89 \\
99.05 \\
47.38 \\
29.84 \\
7.36 \\
0.60\end{array}$ & $\begin{array}{l}0.001 \\
0.001 \\
0.001 \\
\\
0.001 \\
0.001 \\
\text { NS }\end{array}$ \\
\hline
\end{tabular}

0.001 probability level of significance $<1 \% ; 0.01$ probability level of significance $>1 \%$ and $<1 \% ; 0.05$ probability level of significance $>1 \%$ and $<5 \%$; NS probability level of significance $>5 \%$.

duced with increasing oats density only when diclofop-methyl was not applied (tables VI and VIla). In 1984, weight per grain of wheat rose with increasing oats density independently of diclofop-methyl treatment, and in 1985 it was reduced only when diclofop-methyl was not applied (tables VI and VIIb).

Broad-leaf herbicide had no significant effect on the number of grains per ear in 1984 (table VI). In 1985, early applications of broad-leaf herbicide (ioxynil + mecoprop and 2,4-D) increased the number of grains per ear. This effect was dependent upon diclofop-methyl application: early application of 2,4-D increased the number of grains per ear only when diclofop-methyl was applied (table VIIla). Weight per grain was higher in both years when 2,4-D was applied on the same day as diclofop-methyl (table VIIIb).

\section{DISCUSSION}

Although the response of spring wheat to increasing densities of spring oats, considered to be a weed, varied somewhat from year to year, a fundamental pattern for the competitive interactions between wheat, oats and broad-leaf plants and the effects of weed control could be identified. The population density of spring oats was greatly reduced in 1984 between establishment and early tillering (table II); cold weather and soil dryness between emergence and tiller- 
Table IV. Analysis of variance of ear densities of spring wheat as influenced by cultivated oats density, oats and broad-leaf herbicide in 1984, 1985 and 1986 (data from harvest plots).

\begin{tabular}{|c|c|c|c|c|c|}
\hline Year & Factor & $\begin{array}{l}\text { Degrees of } \\
\text { freedom }\end{array}$ & Sum of squares & $F$ value & Probability level \\
\hline \multirow[t]{9}{*}{1984} & $A=$ diclofop-methyl & 1 & 97422 & 41.81 & 0.01 \\
\hline & Error 1 & 4 & 9321 & & \\
\hline & $\mathrm{B}=$ oats density & 5 & 629543 & 44.42 & 0.001 \\
\hline & $A \times B$ & 5 & 2815 & 0.20 & NS \\
\hline & Error 2 & 40 & 113386 & & \\
\hline & $\mathrm{C}=$ broad-leaf herbicide & 2 & 43025 & 13.89 & 0.001 \\
\hline & $A \times C$ & 2 & 18067 & 5.83 & 0.01 \\
\hline & $\mathrm{B} \times \mathrm{C}$ & 10 & 9631 & 0.62 & NS \\
\hline & Error 3 & 106 & 164168 & & \\
\hline \multirow[t]{9}{*}{1985} & $A=$ diclofop-methyl & 1 & 494742 & 102.52 & 0.01 \\
\hline & Error 1 & 4 & 19303 & & \\
\hline & $\mathrm{B}=$ oats density & 5 & 545306 & 60.06 & 0.001 \\
\hline & $A \times B$ & 5 & 13999 & 7.71 & 0.001 \\
\hline & Error 2 & 40 & & & \\
\hline & $\mathrm{C}=$ broad-leaf herbicide & 3 & 48507 & 14.73 & 0.001 \\
\hline & $A \times C$ & 3 & 36650 & 11.13 & 0.001 \\
\hline & $\mathrm{B} \times \mathrm{C}$ & 15 & 18443 & 1.12 & NS \\
\hline & Error 3 & 159 & 174510 & & \\
\hline \multirow[t]{9}{*}{1986} & $A=$ diclofop-methyl & 1 & 32716 & 2.73 & NS \\
\hline & Error 1 & 4 & & & \\
\hline & $\bar{B}=$ oats density & 5 & 538042 & 45.96 & 0.001 \\
\hline & $A \times B$ & 5 & 76503 & 6.53 & 0.001 \\
\hline & Error 2 & 40 & 93659 & & \\
\hline & $\mathrm{C}=$ broad-leaf herbicide & 3 & 46206 & 5.78 & 0.001 \\
\hline & $A \times C$ & 3 & 25660 & 3.21 & 0.05 \\
\hline & $\mathrm{B} \times \mathrm{C}$ & 15 & 29168 & 0.73 & NS \\
\hline & Error 3 & 159 & 423973 & & \\
\hline
\end{tabular}

0.001 probability level of significance $<1 \%$; 0.01 probability level of significance $>1 \%$ and $<1 \% ; 0.05$ probability level of significance $>1 \%$ and $<5 \%$; NS probability level of significance $>5 \%$.

ing may have been partly responsible for the reduced oats seedling density; cv Selma oats appear to be less resistant to cold weather than $\mathrm{cr}$ Bastion wheat. The germinability of spring wheat seeds was slightly lower in 1985 than in 1984 and in 1986. This could explain the reduced wheat population at emergence. As for oats (table $\mathrm{II}$ ), wheat density at stage 22 (283 plants $\left./ \mathrm{m}^{2}\right)$ was still higher than at stage 12 (257 plants $\left./ \mathrm{m}^{2}\right)$, because of the delayed emergence of both cereals. Soil moisture conditions (Bell and Nalewaja, 1968) or relative time of emergence of plants in competition (Peters and Wilson, 1983; O'Donovan et al, 1985) can induce a year-toyear variation in the early development of cereals and grass weeds. Such variation can be taken into account by calculating regression equations between crop yield and weed population density at weed control time, rather than at emergence. Early and mid-season assessments of shoot biomass showed that competition between oats and wheat began early and that the plants having an advantage at establishment enhanced it with time (figs 1-2). Oats were a more successful competitor in 1985 than in 1984 and 1986. The long emergence period probably favored oats competition in 1985. Pavlychenko and Harrington (1934) compared the competitive efficiencies of weeds and cereal crops and showed that, under favorable circumstances wheat varieties can develop greater root systems than those of wild and cultivated oats 5 and $21 \mathrm{~d}$ after emergence. However, as the root systems of cultivated oats, and more specifically wild oats, are con- 


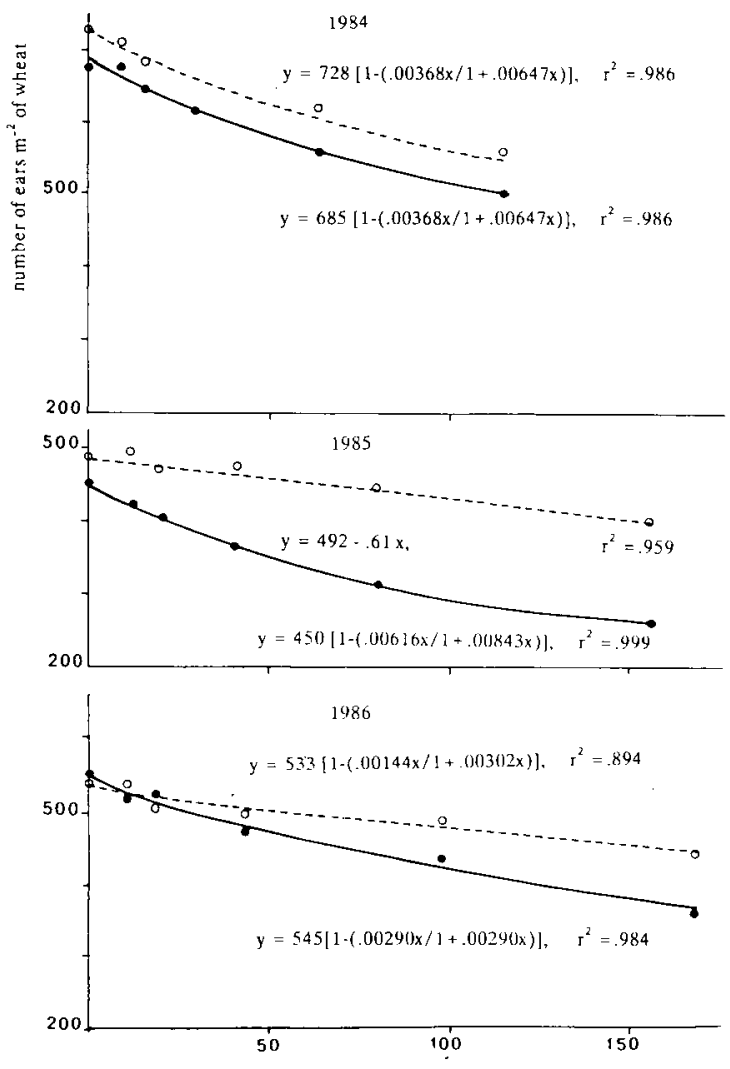

Fig 4. Relationship between oats density at wheat stage 22 and number of ears of wheat with and without diclofop-methyl treatment: ๑๑ no diclofop-methyl; OOO diclofop-methyl. centrated close to the surface while the root system of wheat is deeper, wheat is not such a successful competitor.

Measures of wheat yield (table III) indicate that the 3 experimental factors, oats density, diclofop-methyl treatment and broad-leaf weed control, changed the competition between plants. As 2 of the statistical interactions were significant every year (diclofop-methyl $x$ oats density and diclofop-methyl $x$ broad-leaf herbicide), wheat losses must be discussed in relation to these.

Linear or quadratic equations fitted the data well for describing the yield loss of wheat in relation to oat density (Kafiz, 1989) Fitting a rectangular hyperbola gave a slight improvement because it is a valid model for describing the relationship between crop yield and weed density over a wide range of weed densities (Cousens, 1985; Wilson and Wright, 1990). Our results for plots not treated with diclofop-methyl (fig 3) show that wheat yield losses varied from $5 \%$ to $20 \%$ when oats densities were $10-20$ plants $/ \mathrm{m}^{2}$. These may be regarded as threshold densities for Avena $\mathrm{sp}$ in cereals (Caussanel, 1989). When diclofop-methyl was applied at wheat stage 22 , there were still losses of wheat

Table V. Effect of diclofop-methyl on wheat yield in relation to broad-leaf herbicide treatment.

\begin{tabular}{|c|c|c|c|c|c|}
\hline & & $\begin{array}{l}\text { No broad-leaf } \\
\text { herbicide }\end{array}$ & $\begin{array}{l}\text { loxynil } \\
+ \text { mecoprop }\end{array}$ & $\begin{array}{l}\text { 2,4-D early } \\
\text { application }\end{array}$ & $\begin{array}{l}\text { 2,4-D late } \\
\text { application }\end{array}$ \\
\hline \multicolumn{6}{|c|}{ a) Effect on grain yield ( $\mathrm{kg} / \mathrm{ha}$ ) } \\
\hline 1984 & $\begin{array}{l}\text { No diclofop-methyl } \\
\text { Diclofop-methyl }\end{array}$ & $\begin{array}{l}5958^{a} \\
6609 a\end{array}$ & - & $\begin{array}{l}5911^{\mathrm{a}} \\
7100^{\mathrm{b}}\end{array}$ & $\begin{array}{l}6098^{a} \\
6658^{a}\end{array}$ \\
\hline 1985 & $\begin{array}{l}\text { No diclofop-methyl } \\
\text { Diclofop-methyl }\end{array}$ & $\begin{array}{l}2869 a \\
3377^{a}\end{array}$ & $\begin{array}{l}3086^{\omega} \\
3848^{b}\end{array}$ & $\begin{array}{l}2812^{\mathrm{a}} \\
3890^{\mathrm{b}}\end{array}$ & $\begin{array}{l}2774^{a} \\
3445^{a}\end{array}$ \\
\hline 1986 & $\begin{array}{l}\text { No diclofop-methyl } \\
\text { Diclofop-methyl }\end{array}$ & $\begin{array}{l}7108^{b} \\
8265^{b}\end{array}$ & $\begin{array}{l}7090^{b} \\
8164^{b}\end{array}$ & $\begin{array}{l}6887^{a} \\
7522^{a}\end{array}$ & $\begin{array}{l}7173^{b} \\
8267^{b}\end{array}$ \\
\hline b) Effe & ect on number of ears & & & & \\
\hline 1984 & $\begin{array}{l}\text { No diclofop-methyl } \\
\text { Diclofop-methyl }\end{array}$ & $\begin{array}{l}626^{a} \\
675^{b}\end{array}$ & - & $\begin{array}{l}602^{a} \\
627^{a}\end{array}$ & $\begin{array}{l}610^{\mathrm{a}} \\
681^{\mathrm{b}}\end{array}$ \\
\hline 1985 & $\begin{array}{l}\text { No diclofop-methyl } \\
\text { Diclofop-methyl }\end{array}$ & $\begin{array}{l}375^{a} \\
474^{b}\end{array}$ & $\begin{array}{l}377^{a} \\
473^{b}\end{array}$ & $\begin{array}{l}363^{a} \\
413^{a}\end{array}$ & $\begin{array}{l}361^{a} \\
476^{b}\end{array}$ \\
\hline 1986 & $\begin{array}{l}\text { No diclofop-methyl } \\
\text { Diclofop-methyl }\end{array}$ & $\begin{array}{l}463^{a} \\
507^{b}\end{array}$ & $\begin{array}{l}467^{a} \\
508^{b}\end{array}$ & $\begin{array}{l}476^{a} \\
469^{a}\end{array}$ & $\begin{array}{l}504^{b} \\
518^{b}\end{array}$ \\
\hline
\end{tabular}

Two means with the same superscript on the same line are not significantly different $(P>0.05)$. 
Table VI. Probability levels of significance of main effects and interactions for yield components (data from quadrats).

\begin{tabular}{|c|c|c|c|c|c|c|c|c|}
\hline \multirow[t]{3}{*}{ Effect } & \multicolumn{8}{|c|}{ Year } \\
\hline & \multicolumn{4}{|c|}{1984} & \multicolumn{3}{|c|}{1985} & \multirow[b]{2}{*}{$\begin{array}{l}\text { Weight } \\
\text { grain }\end{array}$} \\
\hline & Yield & $\begin{array}{l}\text { Number } \\
\text { of ears } / m^{2}\end{array}$ & $\begin{array}{l}\text { Number } \\
\text { of grains/ear }\end{array}$ & $\begin{array}{l}\text { Weight } \\
\text { grain }\end{array}$ & Yield & $\begin{array}{c}\text { Number } \\
\text { of ears } / m^{2}\end{array}$ & $\begin{array}{l}\text { Number } \\
\text { of grains/ear }\end{array}$ & \\
\hline Diclofop-methyl & NS & 0.01 & NS & NS & 0.05 & 0.001 & 0.05 & NS \\
\hline Oats density & 0.001 & 0.001 & NS & 0.05 & 0.001 & 0.001 & 0.001 & NS \\
\hline Broad-leaf herbicide & NS & 0.001 & NS & 0.001 & 0.001 & 0.001 & 0.001 & 0.001 \\
\hline $\begin{array}{l}\text { Diclofop-methyl } \\
x \text { oats density }\end{array}$ & 0.05 & NS & 0.05 & NS & 0.001 & 0.001 & 0.001 & 0.01 \\
\hline $\begin{array}{l}\text { Diclofop-methyl } \\
x \text { broad-leaf herbicide }\end{array}$ & NS & 0.01 & NS & 0.001 & 0.001 & 0.001 & 0.001 & 0.001 \\
\hline $\begin{array}{l}\text { Broad-leaf herbicide } \\
x \text { oats density }\end{array}$ & NS & NS & NS & NS & NS & NS & NS & NS \\
\hline
\end{tabular}

0.001 probability level of significance $<1 \%$; 0.01 probability level of significance $>1 \%$ and $<1 \%$; 0.05 probability level of significance $>1 \%$ and $<5 \%$; NS probability level of significance $>5 \%$.

yield every year. Even though they were lower over the whole range of densities, our experiments confirm that oats must be removed before wheat stage 22 to avoid any yield loss, as was found in Canada (Bowden and Friesen, 1967) and in England (Chancellor and Peters, 1974).
The oats density reduced the number of ears/ $\mathrm{m}^{2}$ every year. The reductions on diclofop-methyl treated and untreated plots were similar in 1984 and greater on plots without diclofop-methyl in 1985 and 1986 (fig 4). The reduction in number of grains per ear occurred only in the absence of

Table VII. Effect of oats density on number of grains per ear and weight per grain of wheat in relation to diclofopmethyl treatment.

Density level

\begin{tabular}{llllll}
\hline$A$ & $B$ & $C$ & $D$ & $E$ & $F$
\end{tabular}

a) Number of grains per ear

\begin{tabular}{|c|c|c|c|c|c|c|c|}
\hline 1984 & $\begin{array}{l}\text { No diclofop-methyl } \\
\text { Diclofop-methyl }\end{array}$ & $\begin{array}{l}34.2 \\
33.1\end{array}$ & $\begin{array}{l}33.2 \\
32.8\end{array}$ & $\begin{array}{l}32.4 \\
32.3\end{array}$ & $\begin{array}{l}31.1 \\
32.6\end{array}$ & $\begin{array}{l}29.9 \\
33.5\end{array}$ & $\begin{array}{l}30.5 \\
33.9\end{array}$ \\
\hline 1985 & $\begin{array}{l}\text { No diclofop-methyl } \\
\text { Diclofop-methyl }\end{array}$ & $\begin{array}{l}31.2 \\
27.7\end{array}$ & $\begin{array}{l}30.3 \\
29.7\end{array}$ & $\begin{array}{l}28.5 \\
27.5\end{array}$ & $\begin{array}{l}25.8 \\
27.8\end{array}$ & $\begin{array}{l}24.1 \\
27.9\end{array}$ & $\begin{array}{l}19.2 \\
27.6\end{array}$ \\
\hline b) We & ght per grain (mg) & & & & & & \\
\hline 1984 & $\begin{array}{l}\text { No diclofop-methyl } \\
\text { Diclofop-methyl }\end{array}$ & $\begin{array}{l}29.9 \\
29.1\end{array}$ & $\begin{array}{l}30.2 \\
29.6\end{array}$ & $\begin{array}{l}30.3 \\
29.6\end{array}$ & $\begin{array}{l}30.0 \\
30.4\end{array}$ & $\begin{array}{l}29.8 \\
30.4\end{array}$ & $\begin{array}{l}31.1 \\
32.0\end{array}$ \\
\hline 1985 & $\begin{array}{l}\text { No diclofop-methyl } \\
\text { Diclofop-methyl }\end{array}$ & $\begin{array}{l}31.7 \\
30.4\end{array}$ & $\begin{array}{l}31.7 \\
30.0\end{array}$ & $\begin{array}{l}29.8 \\
29.6\end{array}$ & $\begin{array}{l}30.7 \\
29.9\end{array}$ & $\begin{array}{l}31.1 \\
29.5\end{array}$ & $\begin{array}{l}28.6 \\
30.9\end{array}$ \\
\hline
\end{tabular}


Table VIII. Effect of diclofop-methyl on number of grains per ear and weight per grain of wheat in relation to broadleaf herbicide treatment.

$\begin{array}{llll}\begin{array}{l}\text { No broad-leaf } \\ \text { herbicide treatment }\end{array} & \begin{array}{l}\text { loxynil } \\ + \text { mecoprop }\end{array} & \begin{array}{l}2,4-D \text { early } \\ \text { application }\end{array} & \begin{array}{l}2,4-D \text { late } \\ \text { application }\end{array}\end{array}$

a) Number of grains per ear Diclofop-methyl

$26.2^{\mathrm{a}}$

$25.7^{\mathrm{a}}$

$28.4^{b}$

$28.3^{b}$

$25.1^{\mathrm{a}}$

$31.7^{\mathrm{c}}$

$26.5^{a}$

$26.5^{\mathrm{a}}$

b) Weight per grain (mg)

\begin{tabular}{|c|c|c|c|c|c|}
\hline 1984 & $\begin{array}{l}\text { No diclofop-methyl } \\
\text { Diclofop-methyl }\end{array}$ & $\begin{array}{l}30.0^{a} \\
29.3^{a}\end{array}$ & - & $\begin{array}{l}30.1^{\mathrm{a}} \\
31.3^{\mathrm{c}}\end{array}$ & $\begin{array}{l}30.4^{a} \\
30.0^{b}\end{array}$ \\
\hline 1985 & No diclofop-methyl & $\begin{array}{l}30.3^{a} \\
28.3 a\end{array}$ & $\begin{array}{l}30.7^{a} \\
300^{b}\end{array}$ & $\begin{array}{l}31.0^{\mathrm{a}} \\
330^{\mathrm{c}}\end{array}$ & $\begin{array}{l}30.3^{a} \\
28.8^{a}\end{array}$ \\
\hline
\end{tabular}

Two means with the same superscript on the same line are not significantly different $(P>0.05)$.

diclofop-methyl (table VIla). Wheat submitted to oats competition up to early tillering recovered partly at maturity by an increase in or a maintenance of weight per grain compared to wheat not treated with diclofop-methyl (table VIIb).

The diclofop-methyl $x$ broad-leaf herbicide interaction was significant for crop yield and all yield components measured in the 3 field experiments, except for the number of grains per ear in 1984. In our experimental conditions, where biomass of broad-leaf weeds represented less than $5 \%$ of the total plant dry weight on control "biomass plots", early to late applications of 2,4-D did not increase wheat yield on plots not treated with diclofop-methyl. Early application of 2,4-D was even injurious in 1986 (table V). Control of oats at early tillering resulted in a greater response of wheat to broad-leaf weed control. The removal of grass weeds from mixed infestations of grassy and broad-leaf weeds allows broad-leaf weeds to compete more strongly with cereals (Haizel and Harper, 1973; Koch, 1964). Our results appear to confirm this fact, as when the wheat was exposed to a long period of oats competition from emergence to establishment. Early 2,4-D application in 1984 and early broad-leaf weed control in 1985, gave positive yield responses (table V). A combination of ioxynil + mecoprop proved beneficial when it was applied in addition to the diclofop-methyl, even though the broad-leaf weed infestation was low, as in 1985. In 1986, this infestation was not bad enough to make the treatment profitable (table $V$ and fig 1 ). In field experiments where the soil was naturally infested with both wild oats and wild mustard seeds it was shown that the wheat yield was greatest when both weed species were controlled with diclofop + bromoxynil at the 2-leaf wheat stage (Gillespie and Najewaja, 1988).

The field studies reported here showed no loss of activity on Avena sativa $L$ when diclofopmethyl and 2,4-D were applied separately on the same day at early tillering. Every year showed fewer wheat ears $/ \mathrm{m}^{2}$ (table $\mathrm{Vb}$ ), but this resulted in a lower wheat yield only in 1986 (table Va). The phytotoxic effect appears to have been offset by an increase in the number of grains per ear in 1985 and in weight per grain in 1984 and 1985 (table VIII). As these yield components were not evaluated in 1986, it is not possible to explain why the wheat yield on plots controlled on the same day by diclofop-methyl and 2,4-D remained lower than on control plots when diclofop-methyl was applied alone.

The experiments described here show that the relationship between density of a single grass weed species and final crop yield can be accurately described by linear or non-linear regressions, in relation to weed control time and weed density range. Weed density is the most commonly used parameter in all agronomic studies of crop yield losses used for spraying decisions in post-emergence weed control, and its limits are known in a wider perspective of 
weed-crop competition modelling (Jacquard, 1982; Caussanel, 1989, 1992). Weed-crop competition studies include: i) predictive models where destructive (biomass or relative biomass) or non-destructive parameters (leaf area or relative leaf area) describing the level of infestation measured at an early growth stage can be used in the rectangular hyperbola model for several agronomic production systems (Kropff and Spitters, 1991; Rasmussen, 1991; Caussanel, 1992); and ii) simulation models in which a number of physiological and agronomic parameters are defined to simulate the growth and development of the 2 competing plant species throughout their growth/life cycle (Kiniry et al, 1992; Kropff et al, 1992). As weed-crop competition models represent only a part of the general model for weed population dynamics (Firbank and Watkinson, 1986; Debaeke, 1988), specialized, long-term studies should be made at the field level to obtain a better understanding of weedcrop interactions.

\section{ACKNOWLEDGMENTS}

We thank P Gaillardon (INRA-Dijon) and W Stern (University of Western Australia), for their critical review of the manuscript, MM Bourlier for technical assistance, the staff of the Domaine Experimental d'Epoisses for their help and N Polge and W Stern for revising the English text.

\section{REFERENCES}

Barralis G (1961) Etude de la distribution des diverses espèces de folles avoines en France. Ann Phys Vég 3, 39-53

Bell AR, Nalewaja JD (1968) Competition of wild oats in wheat and barley. Weed Sci 16, 505-508

Bowden BA, Friesen G (1967) Competition of wild oats (Avena fatua $L$ ) in wheat and flax. Weed Res 7, 349-359

Carlson HL, Hill JE (1985) Wild oat (Avena fatua) competition with spring wheat: plant density effects. Weed Sci 33, 176-181

Caussanel JP (1973) Etude préliminaire sur la période de compétition maximale de la flore adventice envers le blé d'hiver. CR Acad Agric Fr, 233-241

Caussanel JP (1989) Nuisibilité et seuils de nuisibilité des mauvaises herbes dans une culture annuelle: situation de concurrence bispécifique. agronomie 9 , $219-240$

Caussanel JP (1992) Modelos biologicos de competencia y umbrales de nocividad en cultivos anuales. Mem Symp Intern Manejo de la maleza : situación actual y perspectivas, 2, Asomecima, Conacyt, Chapingo, Mexico, 281-303

Caussanel JP, Branthome X, Maillet J, Carteron A (1990) Influence de la densité et de la période de concurrence d'une graminée adventice dans un blé de printemps en relation avec le désherbage. Weed Res 28, 309-322

Caussanel JP, Kafiz B, Carteron A (1988) Analyse expérimentale des effets de concurrence d'une graminée adventice dans un blé de printemps en relation avec le désherbage. Weed Res 28, 309-322

Caussanel JP, Kafiz B, Carteron A, Schiex J (1990) Influence de la densité d'une avoine, d'un colza ou d'une vesce sur la perte de rendement d'un blé de printemps en relation avec la date de désherbage chimique ou la structure spatiale du peuplement. Proc EWRS Symp Integrated Weed Management in Cereals, Helsinki (Finland), 255-262

Chancellor RJ, Peters NCB (1974) The time of the onset of competition between wild oats (Avena fatua L) and spring cereals. Weed Res 14, 197-202

Cousens $R$ (1985) A simple model relating yield loss to weed density. Ann Appl Biol 107, 239-252

Cousens R, Peters NCB, Marshall CJ (1984) Models of yield loss-weed density relationships. $C R$ th int Symp Weed Biol Ecol Syst 367-374

Debaeke P (1988) Modélisation de l'évolution à long terme de la flore adventice.II. Application à trois dicotylédones annuelles en un site donné. agronomie $8,767-777$

Dew DA (1972) An index of competition for estimating crop loss due to weeds. Can J PI Sci 52, 921-927

Duncan D (1955) Multiple range and multiple F-tests. Biometrics 11, 1-42

Fernandez-Quintanilla C, Navarette L, Torner C, Andujar JL (1987) Influence of herbicide treatments on the population dynamics of Avena sterilis ssp ludoviciana (Durieu). Nyman in winter wheat crops. Weed Res 27, 375-383

Firbank LG, Watkinson AR (1986) Modelling the population dynamics of an arable weed and its effects upon crop yield. J Appl Ecol 23, 147-159

Friesen G, Shebeski LH (1960) Economic losses caused by weed competition in Manitoba grain fields. I. Weed species, their relative abundance and their effect on crop yields. Can JPI Sci 40, $457-467$

Gillespie GR, Nalewaja JD (1988) Economic control of weeds in wheat, Triticum aestivum. Weed Technol 2, 257-261

Gournay X de (1964) Données relatives à la lutte contre la folle avoine (Avena fatua $L$ ) dans les cultures d'orge de printemps. Ann Epiphyt 15, 285-320

Haizel KA, Harper JL (1973) The effects of density and the timing of removal on interference between barley, white mustard and wild oats. J App/ Ecol 10, 23-31

Holm Leroy G, Plucknett DL, Pancho JV, Herberger JP (1977) The World's Worst Weeds: Distribution 
and Biology. Publ East West Center Univ Press, Honolulu, $\mathrm{Ha}$

Jacquard $P$ (1982) Dynamique des relations de concurrence intraspécifiques, interpopulations et intrapopulations: modèles prévisionnels et de simulation. Acta CEcol, CEcol Gen 3, 183-215

Jauzein P, Montegut J (1983) Graminées (Poaceae) nuisibles en agriculture. Ed SECN (Société d'édition "Champignons et Nature"), Aubervilliers, France, $538 \mathrm{p}$

Kafiz B (1989) Contribution à l'étude des seuils biologiques de nuisibilité de l'avoine (Avena sativa $L$ ) dans une céréale de printemps (Triticum vulgare $L$ ) en relation avec le désherbage chimique et à l'étude de l'interaction entre le diclofopméthyl et le 2,4-D. Ph D Thesis, University of Nancy 1, France, $306 p$

Kafiz B, Caussanel JP, Scalla R, Gaillardon P (1989) Interaction between diclofopmethyl and 2,4-D in wild oat (Avena fatua $L$ ) and cultivated oat (Avena sativa $\mathrm{L}$ ) and fate of diclofopmethyl in cultivated oat. Weed Res 29, 299-305

Kiniry JR, Williams JR, Gassman PW, Debaeke P (1992) A general process-oriented model for two competing plant species. Trans ASAE 35, 801-810

Koch W (1964) Einige Beobachtungen zur Veränderung der Verunkrautung während mehrjahrigen Getreidebaus und verschiedenärtiger Unkrautbekampfung. Weed Res 4, 351-356

Kropff MJ, Spitters CJT (1991) A simple model of crop loss by weed competition from early observations on relative area of the weeds. Weed Res 31, 97-105

Kropff MJ, Spitters JT (1992) An ecophysiological model for interspecific competition, applied to the influence of Chenopodium album $\mathrm{L}$ in sugar beet. I. Model description and parametrization. Weed Res 32, 451-464

Little TM (1981) Interpretation and presentation of results. Hort Sci 16, 637-640

Madeira J, Dordio MF, Mira RS, Lopes S (1984) Population level and concurrence of wild oats (Avena sterilis ssp sterilis) in wheat fields in Portugal. $C R$ 3e Symp Mauvaises Herbes et Désherbage dans le Bassin Méditerranéen, Oeiras, Portugal, EWRS, 461-468

Meynard J (1985) Construction d'itinéraires techniques pour la conduite du blé d'hiver. Docteur-Ingénieur Thesis, INA-PG, Paris, France, 297 p

O'Donovan JT, St Remy A de, O'Sullivan PA, Dew DA, Sharma AK (1985) Influence of the relative time of emergence of wild oat (Avena fatua) on yield loss of barley (Hordeum vulgare) and wheat (Triticum aestivum). Weed Sci 33, 498-503

Paterson JG (1976) The distribution of Avena species naturalised in Western Australia. J Appl Ecol 13, 257-264
Pavlychenko TK, Harrington JB (1934) Competitive efficiency of weeds and cereal crops. Canad J Res $10,77-94$

Peters NCB, Wilson BJ (1983) Some studies on the competition between Avena futua $L$ and spring barley. II. Variation of $A$ fatua emergence and development and its influence on crop yield. Weed Res 23, 305-311

Pfeiffer RK, Holmes HM (1961) A study of the competition between barley and oats as influenced by barley seed rate, nitrogen level and barban treatment. Weed Res 1, 5-18

Rasmussen J (1991) A model for prediction of yield response in weed harrowing. Weed Res 31, 401408

Rolston MP (1981) Wild oats in New Zealand: a review. New Zealand. J Exp Agric 9, 115-121

SAS Institute (1988) SAS/STAT Users' Guide Release. 6.03 Edition, Cary NC, $1028 \mathrm{p}$

Saut $\mathrm{MH}$ (1981) Contribution à l'étude des relations sociales entre le blé d'hiver et le ray-grass raide: rôle des caractéristiques respectives de développement et de croissance des deux espèces. Docteur-Ingénieur Thesis, INA-PG, Paris, $222 \mathrm{p}$

Sebillotte M, Boiffin J, Caneill J, Meynard JM (1978) Sécheresse et fertilisation azotée du blé d'hiver. Essai d'analyse de situations au champ par l'étude des composantes du rendement. Bull Assoc Fr Etude Sol3, 197-214

Taylor HF, Loader MPC, Norris SJ (1983) Compatible and antagonistic mixtures of diclofop-methyl and flamprop methyl with herbicides used to control broad-leaved weeds. Weed Res 24, 185-190

Todd BG, Stobbe EH (1980) The basis of antagonistic effect of 2,4-D on diclofopmethyl toxicity to wild oat (Avena fatua). Weed Sci 28, 371-377

Trenbath BR, Harper JL (1973) Neighbour effects in the genus Avena. I. Comparison of crop species. J Appl Ecol 10, 379-400

Weaver SE, Smits N, Tan CS (1987) Estimating yield losses of tomatoes (Lycopersicon esculentum) caused by nightshade (Solanum spp) interference. Weed Sci 35, 163-168

Wilson BJ, Cussans GW (1978) The effects of herbicides, aplied alone and in sequence, on the control of wild oats (Avena fatua) and broad-leaved weeds, and on yield of winter wheat. Ann Appl Biol 89, 459-466

Wilson BJ, Wright KJ (1990) Predicting the growth and competitive effects of annual weeds in wheat. Weed Res 30, 201-211

Zadoks JC, Chang T, Konzak CF (1974) A decimal code for the growth stages of cereals. Weed Res $14,415-421$ 